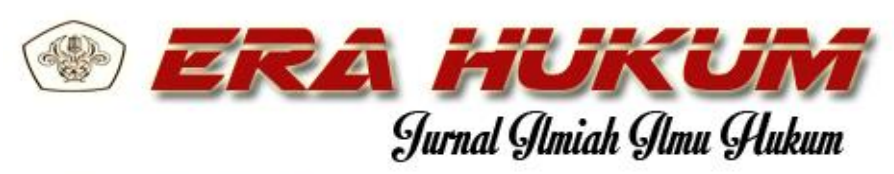

Volume 16, Nomor 1, Juni 2018

ISSN 0854-8242 | e-ISSN 2581-0359

Fakultas Hukum - Universitas Tarumanagara

open Access at: www.journal.untar.ac.id/index.php/hukum

Era Hukum - Jurnal Imiah Ilmu Hukum is licensed under Creative Commons Attrib ution 4.0 International License, which allows otherwriters to use, distribute, and/or build upon this article, as long as the original work is properiy cited.

\title{
QUO VADIS UNDANG-UNDANG POKOK AGRARIA? Suatu Tinjauan Terhadap Permasalahan Pertanahan di Usia Undang-undang Pokok Agraria yang ke Lima Puluh Delapan Tahun
}

\begin{abstract}
Benny Djaja
(Notaris dan PPAT di Jakarta Barat, Dosen Tetap pada Universitas Tarumanagara. Meraih Sarjana Hukum (S.H) dari Universitas Udayana Denpasar (1987), Sarjana Ekonomi (S.E) Universitas Pendidikan Nasional Denpasar (1988), Magister Manajemen (M.M) Universitas Gadjah Mada Yogyakarta (1989), Pendidikan Notariat Universitas Gadjah Mada Yogyakarta (1993), Magister Real Estate (MRE) Central Architectur of Urban Studies Jakarta (2001), Magister Humaniora (M.Hum) Universitas Tarumanegara Jakarta Maret (2002), Magister Kenotaria$\tan$ (M.Kn) Universitas Indonesia Jakarta (2003), Doktor (Dr) Universitas Padjadjaran Bandung (2009)) (E-mail: notaris.bennydjaja@gmail.com)
\end{abstract}

Received: 4 April 2018; Accepted: 6 September 2018; Published: 19 September 2018

\begin{abstract}
:
Disputes in the world of business are not something to write home about. Amongst all the business-related sectors, one that often rears disputes is the agrarian sector. This is due to the close relationship between development and the need for land, as one of the primary needs of humankind. Therefore, a review and comprehensive exposition of disputes within the land sector and aspects of peaceful mediation of said disputes are needed to gain a deeper understanding of ways to achieve more effective and efficient land dispute resolution. In order to achieve these goals and objectives, an in-depth analysis is needed on the extent to which Undang-undang Pokok Agraria (The Agrarian Law) accommodates the resolution of the agrarian disputes and problems, as well as, in relation to the existence of implementing regulations of Undang-undang Pokok Agraria that support the resolution of land disputes that arose or which may arise in the future. Currently disputes over land can be resolved through the means of a lawsuit in the Private Court of Law or through peaceful mediation. Peaceful mediation of land disputes can be carried out both within and outside the Court of Law. Based on the research, mediation in the court has a low rate of success mainly because of the "out for war" mentality of the parties involved which have been formed prior to entering the mediation process. With the settlement of cases through the Judiciary Court of Law becoming a go-to option in the majority of land dispute resolution, the high costs and length of time commonly incurred in such process greatly hampers the resolution of numerous land disputes and tends to be a field of "money war" between litigant parties. If this continues, at its age of 58 years, it must be questioned "Qua Vadis Undang-Undang Pokok Agraria of the Republic of Indonesia?"
\end{abstract}

Keywords: agrarian law, agrarian law anniversary, land ownership, land dispute, land court.

\section{Pendahuluan}

Perselisihan di dunia bisnis ialah hal yang sangat lumrah terjadi. Di dunia modern di mana perkembangan dan pem- bangunan sangat cepat terjadi, persengketaan selalu ada dan menjadi fakta tak terhindarkan dari masyarakat dewasa kini. Tidak semua orang menginginkan terlibat di da- 


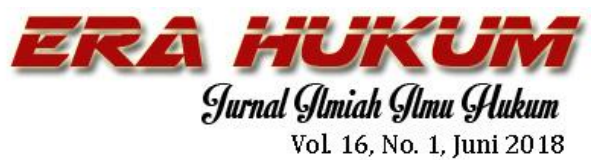

lam suatu sengketa, akan tetapi terkadang sengketa tersebut memang timbul dan telah menjadi suatu faktor yang harus diantisipasii dan dihadapi. Setiap sengketa tersebut perlu diselesaikan, dan tentunya penyelesaian yang terbaik ialah dengan melalui cara perdamaian. Idealnya perdamaian tersebut dicapai dengan musyawarah untuk mencapai suatu win-win solution. Namun pada kenyataannya mencapai kesepakatan perdamaian bukanlah sesuatu yang semudah membalikkan telapak tangan. Suatu sengketa yang tidak bisa diselesaikan melalui cara perdamaian pada akhirnya harus melalui jalur pengadilan ataupun arbitrase yang akan sangat menguras uang, waktu dan tenaga.

Penyelesaian sengketa dengan jalan musyawarah mufakat yang berakhir dengan perdamaian akan selalu lebih baik daripada melalui pengadilan atau pun arbitrase, Penyelesaian sengketa dengan jalan perdamaian memberikan beragam keuntungan antara lain:

i. Waktu yang tidak terbuang;

ii. Biaya yang sangat rendah (tidak perlu membayar biaya perkara dan biaya advokat);

iii. Penyelesaian yang lebih cepat;

iv. Penyelesaian yang relatif lebih adil dan cenderung bersifat win-win.

Perdamaian atau mediasi di Indonesia
Benny Djaja

Quo Vadis Undang-Undang Pokok Agraria...

secara prinsip diatur dalam Kitab UndangUndang Hukum Perdata (KUHPerdata), Reglement Acara Perdata (RBG) dan Reglement Acara Perdata yang Diperbaharui (HIR), serta tersebar dalam peraturan perundang-undangan lainnya yang berlaku di Indonesia antara lain pada Peraturan Mahkamah Agung Nomor 1 Tahun 2016 tentang Prosedur Mediasi di Pengadilan. Perdamaian yang berhasil akan mencapai suatu Kesepakatan atau Perjanjian Perdamaian yang wajib dibuat secara tertulis, dan diatur dalam pasal 1851 KUHPerdata. Pasal tersebut mengatur bahwa Perjanjian Perdamaian dapat mengakhiri suatu perkara yang sedang berlangsung ataupun mencegah timbulnya suatu perkara. Pasal 1858 KUHPerdata kemudian memberi posisi hukum yang sangat kuat terkait perdamaian, di mana segala perdamaian mempunyai kekuatan seperti suatu putusan Hakim dalam tingkat yang terakhir bagi para pihak yang menyepakatinya.

Selanjutnya perlu diteliti lebih lanjut bahwa meskipun perjanjian perdamaian memiliki kedudukan hukum yang kuat, perjanjian perdamaian tetap dapat dibatalkan dengan alasan-alasan sebagai berikut : 


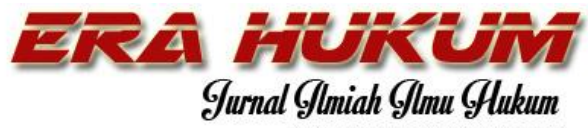

Vol 16, No. 1, Juni 2018

i. terjadi suatu kekhilafan mengenai orang atau mengenai pokok perselisihan;

ii. telah dilakukan penipuan ataupun paksaan;

iii. terjadi kesalahpahaman tentang duduk perkaranya; ${ }^{1}$
Di
dalam
Undang-undang

Penyelesaian Perselisihan Hubungan Industrial, yang secara prinsip mengatur mengenai perselisihan antara pengusaha dengan tenaga kerja, juga diatur bahwa jika terjadi perselisihan hubungan industrial, penyelesaian melalui musyawarah mufakat dapat ditempuh. Apabila tercapai penyelesaian, dibuatlah sebuah perjanjian bersama dan perjanjian bersama tersebut perlu didaftarkan pada Pengadilan Hubungan Industrial pada Pengadilan Negeri di wilayah hukum di mana para pihak mengadakan perjanjian bersama itu. Jika salah satu pihak wanprestasi terhadap pelaksanaan perjanjian bersama tersebut, maka pihak yang dirugikan dapat mengajukan permohonan eksekusi kepada Pengadilan Hubungan Industrial untuk mendapatkan penetapan eksekusi. Hal ini menunjukkan dan menjadi suatu contoh nyata bahwa dalam suatu sengketa selalu terbuka cara

${ }^{1}$ Eddy M. Leks, Panduan Praktis Hukum Properti : Memahami Problematika Hukum Pertanahan, Perumahan, serta Pengembangannya, Cet. I (Jakarta: PT Gramedia Pusaka Utama, 2016), hal. 223.
Benny Djaja

Quo Vadis Undang-Undang Pokok Agraria...

perdamaian dan bahwa perdamaian yang terjadi mempunyai kedudukan hukum yang kuat karena dapat langsung dimohonkan eksekusi apabila ada salah satu pihak yang tidak melaksanakan isi perjanjian bersama tersebut.

Dalam era pembangunan dewasa kini, masalah tanah menjadi permasalahan yang sangat luas dan mendapat banyak perhatian. Hal ini terjadi karena pembangunan dan pengembangan memiliki keterkaitan yang tinggi dengan tanah sebagai salah satu kebutuhan primer manusia, sehingga segala macam aktifitas dalam membangun akan sedikit atau banyak berkaitan dengan bidang pertanahan. Dengan demikian jika dikaitkan dengan hubungannya terhadap sengketa dan perdamaian, maka bidang pertanahan merupakan salah satu bidang hukum di Republik Indonesia yang sangat sering dihadapkan dengan sengketa antara pihak-pihak yang berkepentingan yang merasa mempunyai hak atas suatu bidang tanah ataupun merasa dirugikan oleh suatu perbuatan hukum yang telah dilakukan suatu pihak terkait hak atas tanah.

Berdasarkan pemaparan di atas, sangat tampak bahwa ulasan dan pembahasan yang mendalam mengenai sengketa di bidang pertanahan dan aspek perdamaian atau mediasi di dalamnya sangat diperlukan 


\section{ERA MURUNA \\ Gurnal Glmiah Glmu Glukum \\ Vol 16, No. 1, Juni 2018}

guna memperoleh pengertian yang lebih mendalam lagi mengenai pencapaian penyelesaian sengketa pertanahan yang lebih efektif dan efisien. Demi tercapainya maksud dan tujuan tersebut, diperlukan analisa yang mendalam terkait sejauh mana Undang-undang Pokok Agraria mengakomodir penyelesaian masalah agraria, serta terkait keberadaan peraturan-peraturan pelaksanaan dari Undang-undang Pokok Agraria yang mendukung penyelesaian sengketa pertanahan yang muncul.

\section{Sejauh Mana Undang-Undang Pokok Agraria Mengakomodir Penyelesaian Masalah Agraria}

Berdasarkan penelitian penulis, ${ }^{2}$ secara garis besar terdapat delapan tipologi kasus pertanahan yang sering ditangani oleh $\mathrm{Ke}$ menterian Agraria dan Tata Ruang / Badan Pertanahan Nasional. Tipologi tersebut dengan urutan berdasarkan frekuensinya ialah :

a. Kasus penguasaan dan pemilikan tanah yang secara umum terbagi menjadi dua jenis. Yang pertama yaitu konflik penguasaan dan pemilikan terkait kehutanan yang disebabkan oleh

\footnotetext{
2 Wawancara dengan Siti Hafsiah, S.H., Ketua Bagian Program dan Hukum pada Badan Pertanahan Pusat, dilakukan di Jakarta pada hari Jumat, tanggal 6 April 2018.
}

Benny Djaja Quo Vadis Undang-Undang Pokok Agraria...

kepemilikan peta-peta tersendiri oleh masing-masing instansi, misalnya Departemen Kehutanan dan Badan Pertanahan Nasional. Sebagai contoh yaitu dalam hal pemetaan Badan Pertanahan Nasional terdapat daerah pemukiman yang telah ditinggali penduduk yang pada pemetaan Kementerian Kehutanan masih merupakan daerah hutan dan kemudian diberikan hak penguasaannya kepada suatu pihak. Alhasil penentuan batasbatas penguasaan dan pemilikan tanah atas tanah tersebut dapat menjadi tumpang tindih, rancu dan menimbulkan kasus sengketa penguasaan dan pemilikan tanah.

Yang kedua yaitu konflik terkait aset Badan Milik Negara atau Badan Usaha Milik Negara. Jenis kedua ini banyak terkait dengan asset-aset tanah yang dikuasai oleh Tentara Nasional Indonesia (TNI) sebagai Badan Milik Negara. Dalam kasus seperti ini mediasi pun sangat sulit dilakukan karena instansi Negara sangat sulit untuk melepaskan aset. Kesalahan prosedur dan birokrasi dalam pelepasan aset dapat berakhir dengan tuntutan pidana bagi pejabat yang memfasilitasi pelepasan hak atas aset 
tersebut. Bahkan jika sengketa pun telah berakhir dengan putusan pengadilan, pada kenyataannya eksekusi atas putusan tersebut pun tidaklah mudah. Walaupun kemudian pembatalan sertipikatnya sudah dilakukan oleh Badan Pertanahan Nasional, pemberian hak baru kepada pemenang perkara di pengadilan pun belum bisa dilakukan sampai asetnya dilepas atau dihapuskan dari daftar aset yang dikuasai Negara.

b. Kasus pertanahan karena penetapan hak dan pendaftaran tanah yang terjadi karena adanya kesalahan data baik secara fisik maupun yuridis oleh pemohon pendaftaran tanah, atau adanya unsur ketidak telitian pejabat pendaftaran tanah yang menyebabkan timbulnya kerancuan pada sertipikat yang diterbitkan dan / atau atas kepemilikan hak atas tanah bersangkutan. Kasus pertanahan karena penetapan hak dan pendaftaran tanah ini juga dapat terjadi karena penipuan dan pemalsuan data-data yang digunakan sebagai dasar pendaftaran nama, kasus mana dapat juga berujung pidana di samping sengketa pertanahan. c. Kasus pertanahan terkait batas / letak bidang tanah disebabkan karena adanya kesalahan dalam penunjukan batas atau loksai tanah pada fase pengukuran untuk pendaftaran tanah yang menyebabkan adanya tumpang tindih atau kerancuan kepemilikan hak atas tanah secara fisik. Ketidak telitian dalam pengukuran pun dapat menyebabkan timbulnya kasus pertanahan karena batas / letak bidang tanah di kemudian hari.

d. Kasus pertanahan terkait pengadaan tanah untuk kepentingan umum, yakni kebanyakan yang terjadi ialah sengketa pertanahan yang disebabkan oleh halhal terkait ganti rugi atas obyek untuk pengadaan tanah. Hal ini dapat saja terjadi karena tidak adanya kesepakatan harga ganti rugi, kerancuan batas-batas maupun syaratsyarat pembebasan lahan, atau pun adanya kesalahan terhadap pihak mana ganti rugi atas obyek pengadaan dibayarkan, sementara atas tanah-tanah tersebut fisiknya sudah dikuasai untuk kepentingan umum.

e. Sengketa tanah obyek landeform yang dilaksanakan berdasarkan Peraturan Pemerintah Nomor 2 Tahun 1961 


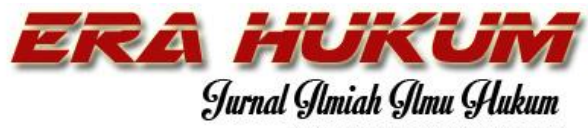

vol 16, No. 1, Juni 2018

tentang Penentuan Perusahaanperusahaan Belanda yang Dikenakan Nasionalisasi. Program landreform memberikan hak-hak atas tanah kepada sebagian masyarakat-masyarakat Republik Indonesia dari petani golongan bawah di daerah-daerah yang ditentukan untuk diusahakan menjadi lahan pertanian mereka. Sengketa atas obyek landreform ini dapat terjadi karena kesalahan pada pendaftaran nama petani penerima obyek landreform, obyek landreform yang diberikan kepada orang yang ternyata bukan petani, atau tanah obyek landreform tersebut belum dibayar ganti rugi pelepasan haknya kepada pemilik tanah sebelumnya, atau pun terjadi kesalahan terhadap pihak siapa ganti rugi tersebut seharusnya dibayarkan.

f. Tuntutan ganti rugi atas tanah partikelir yang menurut UndangUndang Nomor 1 Tahun 1958 tentang Penghapusan Tanah-tanah Partikelir penghapusan atasnya dilakukan dengan ganti rugi berupa uang atau aset berupa tanah lainnya (roeslacht). Tuntutan atas ganti rugi tersebut dapat dilakukan bila ganti rugi tersebut terbukti belum dibayarkan kepada pihak yang berhak
Benny Djaja Quo Vadis Undang-Undang Pokok Agraria...

atasnya sepanjang tanahnya masih ada dan dikuasasi secara fisik oleh pihak yang berhak atas ganti rugi tersebut, serta terdapat bukti pelunasan Pajak Bumi dan Bangunan atas tanah dimaksud.

g. Sengketa atas tanah ulayat yang mana diakui sepanjang ada peraturan daerah yang mengatur keberadaannya. Persyaratan adanya hak ulayat ialah adanya tanah, adanya masyarakat adat yang menguasai tanah tersebut, dan adanya hak yang mana diatur dalam peraturan daerah. Hak ulayat masih banyak terdapat di daerah-daerah Sumatera, Jambi, Nusa Tenggara Barat dan Papua. Pada kenyataannya, banyak masyarakat yang mengaku bagian dari masyarakat adat dan mengaku memiliki hak atas tanah ulayat padahal tidak pernah ada peraturan daerah yang mengatur mengenai keberadaan haknya. Hal ini menimbulkan konflik sengketa pertanahan terkait kepemilikan hak atas tanah ulayat. Sebagai informasi tambahan, antara tahun 1990-an kurang lebih 500 peraturan daerah terkait tanah ulayat sudah dibatalkan oleh Kementerian Dalam Negeri Republik Indonesia. 


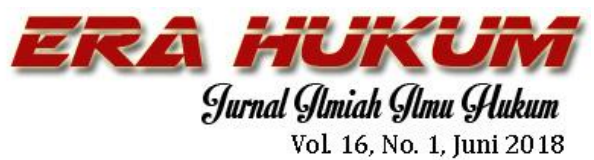

h. Kasus pertanahan terkait pelaksanaan putusan pengadilan, yakni umumnya disebabkan adanya beberapa putusan pengadilan yang amar putusannya bertentangan satu sama lain terhadap satu obyek hak atas tanah yang sama. Dampaknya ialah pelaksanaan putusan pengadilan tersebut menjadi buah simalakama bagi Badan Pertanahan Nasional yang wajib mematuhi putusan pengadilan tersebut. Contoh kasus pertanahan semacam ini ialah kasus sengketa Graha Metropolitan Nuansa yang letak lokasinya berada di dekat Ratu Plaza, Jalan Jenderal Sudirman, Jakarta.

Berdasarkan pemaparan tersebut, di bawah ini dijelaskan beberapa akar masalah yang menjadi sumber sengketa di bidang pertanahan.

\section{A. Sengketa Tanah yang Bersumber dari Kerancuan Pendaftaran Tanah}

Salah satu maksud pembuat undangundang dalam Pembentukan UndangUndang Nomor 5 Tahun 1960 tentang Peraturan Dasar Pokok-Pokok Agraria (UUPA) adalah untuk meletakkan dasar-dasar demi memberikan kepastian dan perlindungan hukum mengenai hak atas tanah bagi seluruh rakyat Indonesia. Untuk alasan
Benny Djaja

Quo Vadis Undang-Undang Pokok Agraria...

demikian-lah yang akhirnya melandasi keberadaan pasal 19 ayat (1) dan (2) yang berbunyi sebagai berikut:

“(1) Untuk menjamin kepastian hukum oleh pemerintah diadakan pendaftaran tanah di seluruh wilayah Republik Indonesia menurut ketentuan-ketentuan yang diatur dalam Peraturan Pemerintah.

(2) Pendaftaran tanah dalam ayat (1) pasal ini meliputi :

a. Pengukuran, perpetaan dan pembukuan tanah;

b. Pendaftaran hak-hak atas tanah dan peralihan hak-hak tersebut;

c. Pemberian surat-surat tanda bukti hak, yang berlaku sebagai alat bukti yang kuat."

Atas dasar pasal 19 ayat (1) dan (2) UUPA tersebut, pada tahun 1961 pertama kali dikeluarkan Peraturan Pemerintah di bidang Pendaftaran Tanah yaitu Pertaturan Pemerintah Nomor 10 Tahun 1961 tentang Pendaftaran Tanah demi memberikan kepastian hukum dan perlindungan hukum terhadap hak atas tanah. Peraturan Pemerintah mengenai Pendaftaran Tanah tahun 1961 ini masih menganut stelsel negatif murni. ${ }^{4}$ Sistem ini kemudian disem-

3 Indonesia, . Undang-Undang Peraturan Dasar Pokok-Pokok Agraria Nomor 5 Tahun 1960, LN No.104 Tahun 1960, TLN No.2043, pasal 19 ayat (1) dan ayat (2).

4 Kementerian Agraria dan Tata Ruang / Badan Pertanahan Nasional, Anotasi Putusan Pengadilan 


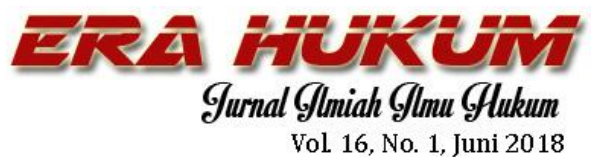

purnakan atau dikembangkan oleh Peraturan Pemerintah Nomor 24 Tahun 1997 tentang Pendaftaran Tanah yang menganut stelsel negatif mengandung unsur positif. Stelsel negatif dengan unsur positif ini menghasilkan sertipikat hak atas tanah sebagai tanda bukti hak yang berlaku sebagai alat pembuktian yang kuat. ${ }^{5}$

Sistem pendaftaran tanah dengan stelsel negatif murni, sebagaimana dianut Peraturan Pemerintah Nomor 10 Tahun 1961 tentang Pendaftaran Tanah pada esensinya berarti pembukuan suatu hak di dalam daftar buku tanah atas nama seseorang tidak mengakibatkan orang yang seharusnya berhak atas tanah itu kehilangan haknya. ${ }^{6}$ Dalam pembentukan peraturan pendaftaran tanah berikutnya, sistem ini dianggap kurang memberikan kepastian hukum kepemilikan hak atas tanah.

Sistem pendaftaran tanah dengan stelsel positif murni berarti bahwa apa yang sudah terdaftar dalam daftar buku tanah ialah dijamin kebenaran datanya dan untuk itu pemerintah meneliti kebenaran dan sahnya tiap warkah yang diajukan untuk

Mengenai Pertanahan Jilid 5 (Terkait pasal 32 Ayat (2) Peraturan Pemerintah Nomor 24 Tahun 1997 Tentang Pendaftaran Tanah, Cet. 1 (Jakarta : Biro Hukum dan Hubungan Masyarakat Kementerian Agraria dan Tata Ruang / Badan Pertanahan Nasional, 2015), hal. 2.

${ }^{5}$ Ibid.

${ }^{6}$ Ibid. hal. 9.
Benny Djaja

Quo Vadis Undang-Undang Pokok Agraria...

didaftarkan sebelum hal itu dimasukkan dalam daftar-daftar. ${ }^{7}$ Dalam sistem ini pendaftaran menciptakan suatu hak yang tidak dapat diganggu gugat dan menimbulkan kondisi di mana "the register is everything" atau untuk memutuskan adanya suatu hak atas tanah dan siapa pemegangnya cukup dengan melihat buku tanahnya. Jika terjadi kesalahan pendaftaran tanah karena kesalahan pejabat pendaftaran, maka pemilik hak sesungguhnya hanya dapat menuntut pemberian ganti rugi atau kompensasi berupa uang. Untuk itu Negara menyediakan apa yang disebut sebagai suatu "assurance fund".

Peraturan Pemerintah Nomor 24 Tahun 1997 tentang Pendaftaran Tanah yang masih tetap berlaku hingga hari ini menganut sistem pendaftaran tanah dengan stelsel negatif mengandung unsur positif. Hal ini dapat dilihat dari pasal 32 peraturan pemerintah tersebut yang mengatur bahwa :

“(1) Sertipikat merupakan surat tanda bukti hak yang berlaku sebagai alat pembuktian yang kuat mengenai data fisik dan data yuridis yang termuat di dalamnya, sepanjang data fisik dan data yuridis tersebut sesuai dengan data yang ada dalam surat ukur dan buku tanah hak yang bersangkutan.

${ }^{7}$ Ibid. 


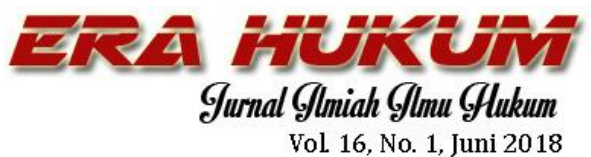

(2) Dalam hal atas suatu bidang tanah sudah diterbitkan sertipikat secara sah atas nama orang atau badan hukum yang memperoleh tanah tersebut dengan itikad baik dan secara nyata menguasainya, maka pihak lain yang merasa mempunyai hak atas tanah itu tidak dapat lagi menuntut pelaksanaan hak tersebut apabila dalam waktu 5 (lima) tahun sejak diterbitkannya sertipikat itu telah tidak mengajukan keberatan secara tertulis kepada pemegang sertipikat dan Kepala Kantor Pertanahan yang bersangkutan ataupun tidak mengajukan gugatan ke Pengadilan mengenai penguasaan tanah atau penerbitan sertipikat tersebut."

Sebagai penjelasan dari pasal tersebut, ayat (1) dari pasal 32 Peraturan Pemerintah Nomor 24 Tahun 1997 tersebut berarti bahwa sistem publikasi pendaftaran tanah yang dianut ialah sistem publikasi negatif, yaitu bahwa sertipikat hanya merupakan surat tanda bukti yang mutlak dan harus diterima oleh hakim sebagai keterangan yang benar selama dan sepanjang tidak ada alat bukti lain yang membuktikan sebaliknya. Dengan demikian berarti Negara tidak menjamin kebenaran data fisik dan data yuridis yang disajikan dan tidak adanya jaminan bagi pemilik sertipikat, karena sewaktu-waktu dapat digugat oleh pihak lain yang merasa dirugikan atas diterbitkannya sertipikat.
Benny Djaja

Quo Vadis Undang-Undang Pokok Agraria...

Ayat (2) dari pasal diatas menutupi ketidakpastian yang menjadi kelemahan ayat (1) dari pasal 32 Peraturan Pemerintah tersebut dengan memberikan perlindungan hukum kepada pemilik sertipikat serta sifat tanda bukti mutlak bagi sertipikat yang tidak dapat diganggu gugat apabila telah memenuhi unsur-unsur secara kumulatif, yaitu:

“1. Sertipikat diterbitkan secara sah atas nama orang atau badan hukum;

2. Tanah diperoleh dengan itikad baik;

3. Tanah dikuasai secara nyata;

4. Dalam waktu lima tahun sejak diterbitkannya sertipikat itu tidak ada yang mengajukan keberatan secara tertulis kepada pemegang sertipikat dan kepala kantor pertanahan kabupaten/kota setempat ataupun tidak mengajukan gugatan ke pengadilan mengenai penguasaan tanah atau penerbitan sertipikat." 8

Menurut Prof. Dr. Maria S.W. Sumardjono, S.H., MCL. MPA, hukum menghendaki kepastian mengenai pemegang hak milik atau hak-hak lain atas sebidang tanah. Namun demikian menurut Dr. Irawan Soerodjo, S.H., MSi., ketentuan bahwa setelah lima tahun sertipikat tanah menjadi tidak dapat diganggu gugat tersebut, walaupun disatu sisi memberikan

${ }^{8}$ Ibid. hal 5-6. 


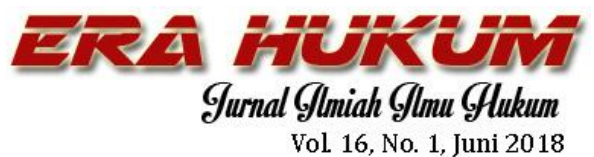

kepastian hukum dan perlindungan hukum, namun disisi lain juga riskan dan tidak memberikan perlindungan hukum kepada rakyat kecil yang sejauh ini belum sepenuhnya paham hukum. ${ }^{9}$

Penulis sepaham dengan pendapat Maria S.W. Sumardjono di atas yaitu bahwa sistem pendaftaran tanah dengan stelsel negatif mengandung kecenderungan positif ini dapat menimbulkan kemungkinan sengketa tanah. Sebut saja dalam hal terjadi kesalahan penyampaian data oleh pemohon pendaftaran tanah dan kemudian selama lima tahun sejak sertipikat diterbitkan, pemilik sesungguhnya yang berhak atas tanah tersebut ialah rakyat kecil yang tidak mengerti hukum dan tidak mengetahui atas kesalahan pendaftaran tanah yang terjadi atas tanahnya. Dalam kondisi kemudian setelah lima tahun berlalu sejak penerbitan sertipikat, maka pendaftaran atas tanah yang mengandung kesalahan tersebut menjadi terlegitimasi mutlak dan sangat merugikan pemegang hak sebenarnya yang kemudian pasti akan memunculkan sengketa terhadap hak atas tanah tersebut. Kelemahan tersebut belum memperhitungkan kemungkinan adanya penipuan, pemalsuan, atau bahkan ketidak telitian pejabat pendaftaran tanah dalam penerbitan

${ }^{9}$ Ibid. hal. 7.
Benny Djaja

Quo Vadis Undang-Undang Pokok Agraria...

sertipikat pada saat pendaftaran tanah.

\section{B. Sengketa Tanah yang Bersumber Peristiwa Pewarisan}

Menurut Pitlo, "hukum waris adalah kumpulan peraturan yang mengatur hukum mengenai kekayaan karena wafatnya seseorang, yaitu mengenai pemindahan kekayaan yang ditinggalkan oleh yang meninggal dan akibat dari pemindahan ini bagi orang-orang yang memperolehnya, baik dalam hubungan antara mereka maupun dengan pihak ketiga" (Pitlo, 1986:1). ${ }^{10}$ Sedangkan menurut Vollmar, "Hukum waris adalah perpindahan dari sebuah harta kekayaan seutuhnya, jadi keseluruhan hakhak dan kewajiban, dari orang yang mewariskan kepada warisnya" (Vollmar, 1989:373). ${ }^{11}$ Hukum pewarisan merupakan salah satu contoh keberlakuan dualisme hukum di Indonesia yang pemberlakuannya dibagi berdasarkan golongan dan agama / kepercayaan, dan merupakaan sisa-sisa dari keberlakuan sistem golongan pada masyarakat Indonesia pada zaman kolonial Belanda terdahulu sebagaimana diatur da-

\footnotetext{
10 Kementerian Agraria dan Tata Ruang / Badan Pertanahan Nasional, Anotasi Putusan Pengadilan Mengenai Pertanahan Tentang Waris, Cet. 1 (Jakarta : Biro Hukum dan Hubungan Masyarakat Kementerian Agraria dan Tata Ruang / Badan Pertanahan Nasional, 2016), hal. 37.

${ }^{11}$ Ibid.
} 


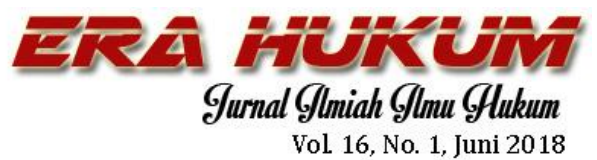

lam pasal 131 juncto 163 Indische Staatsregeling. Secara garis besar hukum waris di Indonesia terdapat dua macam, yaitu :

a. Hukum Waris Tertulis yang terdapat dalam peraturan perundang-undangan dan yurisprudensi, yaitu khususnya Hukum Waris Perdata (berlaku bagi golongan Tionghoa) dan Hukum Waris Islam (berlaku bagi golongan Pribumi beragama Islam);

b. Hukum Waris Adat (berlaku bagi golongan Pribumi beragama nonIslam) yang ialah hukum waris yang hidup dan tumbuh dalam masyarakat adat.

Salah satu sumber obyek sengketa dalam kehidupan sehari-hari antar manusia, terutama dalam suatu keluarga yang tadinya bersatu kemudian menjadi terceraiberai, adalah persoalan pembagian warisan yang tidak proporsional sesuai dengan hukum yang berlaku. Dalam hukum waris, pembagian harta warisan yang diberikan kepada ahli waris dalam prosesnya dapat berlangsung tanpa atau dengan timbulnya sengketa. Pada prinsipnya, pembagian waris ini berlangsung dengan prinsip musyawarah oleh keluarga secara internal untuk menentukan bagian masing-masing ahli waris. Tidak ditemukannya mufakat dalam musyawarah tersebut dapat berujung kepada sengketa. Sengketa tersebut kemudian
Benny Djaja

Quo Vadis Undang-Undang Pokok Agraria...

dapat diusahakan untuk diselesaikan secara musyawarah untuk mencapai mufakat kembali atau, jika tidak, diselesaikan melalui pengadilan.

Asni Zubair, dalam risetnya yang mengambil pendekatan Anthropological Study of Law, mengungkapkan bahwa, ratarata penyebab timbulnya konflik / sengketa dalam pembagian harta warisan dapat berasal dari faktor internal, seperti adanya hibah orang tua kepada bakal ahli waris, tetapi tidak adil dan tidak disertai akta hibah, pasangan suami istri (sebagai bakal pewaris) yang tidak memiliki anak atau keturunan, keserakahan ahli waris, ketidakpahaman ahli waris, kekeliruan dalam menegakkan siri' dan tertundanya pembagian harta warisan atau pun penyebab konflik atau sengketa yang berasal dari faktor eksternal, seperti: adanya anak angkat yang diberi hibah oleh orang tua angkatnya, hadirnya provokator, dan harta warisan dipinjamkan kepada kerabat yang bukan ahli waris dan tidak dikembalikan. ${ }^{12}$

Dalam praktiknya, peristiwa pewarisan merupakan salah satu sumber permasalahan sengketa tanah yang utama. Kasus pertanahan sejenis ini bisa saja terjadi oleh ka-

12 Asni Zubair, http://roufartikel.blogspot.com/2012/11/penyelesaian-hukumwaris.html, Disertasi Uin Sunan Kalijaga, 2013, diunduh pada Senin, 9 April 2018, jam 13.30 WIB. 


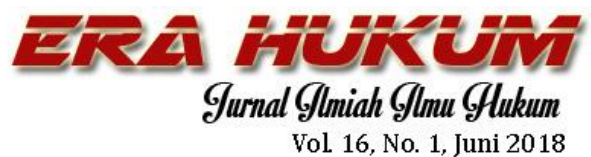

rena hak atas tanah yang tercatat atas nama beberapa orang sebagai ahli waris, kemudian salah satu dari mereka telah menjual obyek tanah tersebut tanpa persetujuan yang lainnya. Atau dalam contoh lainnya yaitu dalam hal suatu obyek hak atas tanah merupakan harta warisan yang belum dibaliknamakan kepada para ahliwaris, namun dijual oleh beberapa ahli waris kepada pihak lain dengan menyembunyikan keberadaan ahli waris lainnya. Dalam keadaan-keadaan tersebut tentunya para ahli waris yang dirugikan akan menggugat haknya atas tanah tersebut dan menimbulkan sengketa pertanahan yang bersumber pada pewarisan.

Lembaga Penyelesaian Sengketa Waris, berdasarkan masing-masing hukum pewarisan yang berlaku terhadapnya, dapat dilakukan di Pengadilan/litigasi Perdata untuk Hukum Waris Perdata, Peradilan Agama untuk Hukum Waris Islam, Peradilan Perdata dalam sebagian kasus juga menjadi lembaga peradilan yang mengadili sengketa Hukum Waris Adat. Penyelesaian sengketa waris juga dapat dilakukan di luar pengadilan/ non litigasi, pada Lembaga Hukum Adat untuk Hukum Waris Adat, ataupun dapat melalui Arbitrase dan Konsiliasi. Sengketa waris adat juga dapat diselesaikan melalui Pengadilan Negeri di
Benny Djaja

Quo Vadis Undang-Undang Pokok Agraria...

tempat berlakunya Hukum Adat tersebut.

\section{Sengketa Pertanahan: Proses Mediasi dan Keberadaan Peraturan- peraturan Pelaksanaan dari Undang-undang Pokok Agraria Sebagai Payung Hukum untuk Penyelesaian Sengketa Pertanahan}

Secara esensi, kasus sengketa pertanahan merupakan konflik kepentingan di bidang tanah, di antaranya sengketa antara individu dan individu, perorangan dengan badan hukum, badan hukum dengan badan hukum dan sebagainya. Berkaitan dengan hal tersebut di atas, untuk kepastian hukum yang diamanatkan oleh UUPA, maka untuk kasus pertanahan yang disebutkan, antara lain dapat diberikan tanggapan / reaksi / penyelesaian kepada para pemangku kepentingan (masyarakat dan pemerintah), berupa solusi melalui Badan Pertanahan Nasional dan solusi melalui Badan Peradilan.

Mediasi atau perdamaian adalah upaya penyelesaian konflik dengan melibatkan pihak ketiga yang bersifat netral dan berperan sebagai penengah guna membantu pihak-pihak yang bersengketa mencapai penyelesaian (solusi) yang diterima oleh kedua belah pihak. Hasil dari penyelesaian konflik tersebut ialah berupa Kesepakatan Perdamaian. Kesepakatan Perdamaian ada- 


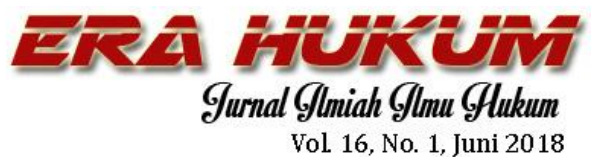

lah kesepakatan hasil mediasi dalam bentuk dokumen yang memuat ketentuan penyelesaian sengketa yang ditandatangani para pihak dan Mediator. ${ }^{13}$ Kesepakatan perdamaian pada esensinya merupakan kesepakatan win-win solution yang dicapai pada akhir mediasi yang merupakan wujud pengakhiran sengketa dan wajib dituangkan dalam bentuk tertulis.

Di Indonesia terdapat dua jenis mediasi atau perdamaian yang dapat ditempuh dalam hal terjadi sengketa di bidang pertanahan. Yang pertama dari jenis-jenis mediasi ini ialah mediasi di dalam pengadilan, yang mana dilakukan oleh dan dengan hakim mediator, atau pun dengan mediator independen berlisensi sebagai penengah. Jenis mediasi kedua adalah mediasi di luar jalur pengadilan, yang dalam hal sengketa pertanahan dilakukan oleh Badan Pertanahan Nasional.

\section{A. Mediasi dalam Pengadilan}

Peraturan Mahkamah Agung Republik Indonesia Nomor 1 Tahun 2016 menyatakan bahwa semua perselisihan perdata, dengan pengecualian beberapa perkara spesifik yang diatur dalam pasal 4 Peraturan

13 Mahkamah Agung Republik Indonesia, Pertaturan Mahkamah Agung Nomor 1 Tahun 2016 Tentang Prosedur Mediasi Di Pengadilan, Pasal 1 ayat (8) juncto pasal 27 ayat (1).
Benny Djaja

Quo Vadis Undang-Undang Pokok Agraria...

Mahkamah Agung tersebut, yang diajukan ke Pengadilan Negeri terlebih dahulu mencari penyelesaian. melalui kedamaian dengan bantuan mediator. ${ }^{14}$ Prosedur mediasi dalam pengadilan terlebih lanjutnya ialah sebagaimana akan diuraikan di bawah ini.

Tahapan pertama yang ditempuh dalam hal mediasi dilakukan dengan hakim dalam pengadilan sebagai mediator ialah tahap pra-mediasi. Pada tahap ini, dalam waktu 7 (tujuh) hari apabila para pihak berdomisili pada kota/kabupaten yang sama dengan Pengadilan Negeri yang menangani perkara atau 14 (empatbelas) hari jika salah satu pihak berdomisili pada kota/kabupaten yang berbeda dari Pengadilan Negeri yang menangani perkara, hakim akan mewajibkan para pihak untuk hadir dan saling menengahi permasalahan di dalam persidangan dan dengan waktu yang ditentukan oleh para pihak. Hakim mendorong para pihak, baik melalui perwakilan kuasa atau langsung kepada para pihak, untuk mengambil peran langsung atau aktif dalam proses mediasi. Dalam tahap pra-mediasi ini hakim juga harus menjelaskan prosedur mediasi menurut Peraturan Mahkamah Agung Nomor 1 tahun 2016 kepada pihakpihak yang bersengketa, termasuk bahwa

${ }^{14}$ Ibid., Pasal 4. 


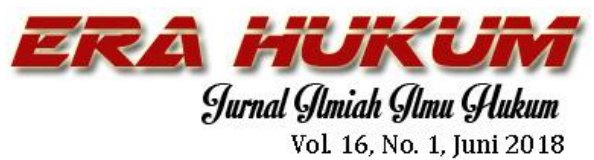

mediasi dimungkinkan untuk dilakukan melalui Pengadilan Negeri.

Dalam proses mediasi di pengadilan, para pihak memiliki hak untuk memilih mediator dari opsi sebagai berikut:

a. Hakim bukan pemeriksa pengadilan di pengadilan yang bersangkutan;

b. Advokat atau akademisi hukum;

c. Profesi non-hukum dianggap sebagai tuan rumah atau pengalaman dalam masalah perselisihan;

d. Hakim dari pemeriksa kasus ini;

e. Kombinasi mediator memanggil a dan $\mathrm{d}$, atau kombinasi dari $\mathrm{b}$ dan d, atau kombinasi c dan d. Jika dalam proses mediasi ada lebih dari satu mediator, tugas mediator ditentukan dan disepakati oleh para mediator sendiri.

Dalam waktu paling lambat dua hari kerja setelah pertemuan pertama para pihak di hari pertama persidangan, hakim mewajibkan para pihak untuk bernegosiasi memilih mediator, termasuk juga terkait biaya-biaya yang mungkin timbul dari pilihan mediator tersebut, pada hari yang sama atau dalam waktu paling lambat 2 (dua) hari kerja. Jika setelah jangka waktu maksimal 2 (dua) hari, para pihak tidak dapat menyetujui pemungutan suara untuk pemilihan mediator yang dimaksud, maka para pihak harus mengajukan kegagalan untuk memilih mediator tersebut kepada
Benny Djaja Quo Vadis Undang-Undang Pokok Agraria...

ketua majelis hakim. Setelah penerimaan pemberitahuan dari para pihak tentang kegagalan memilih mediator tersebut, hakim ketua harus segera menunjuk hakim, yang bukan merupakan hakim pemeriksa utama kasus yang ditangani, pada pengadilan yang sama untuk melakukan fungsi mediator. Mediator kemudian harus mendorong para pihak untuk mengeksplorasi kepentingan mereka guna menemukan solusi terbaik bagi para pihak.

Tahapan selanjutnya yang akan ditempuh setelah penentuan siapa yang menjadi Mediator para pihak ialah tahapan proses mediasi. Dalam jangka waktu maksimal 5 (lima) hari kerja setelah tercapainya kesepakatan para pihak dalam menunjuk mediator, masing-masing pihak dapat mengajukan resume satu dengan yang lain dan kepada mediator. Dalam proses ini, kemudian mediator akan melakukan pemanggilan kepada para pihak untuk melakukan mediasi yang dapat dilakukan sebanyak dua kali. Apabila setelah dua kali pemanggilan salah satu dari para pihak atau kedua-duanya tetap tidak hadir, maka mediasi dianggap gagal. Dalam hal mediasi dianggap gagal, maka mediator akan membuat rekomendasi gagalnya mediasi kepada Majelis Hakim yang menangani perkara yang mana akan menjadi 


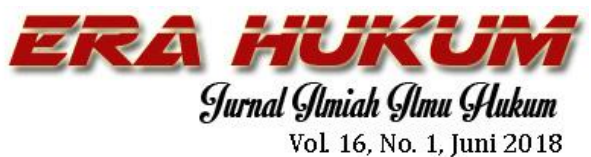

pertimbangan bagi hakim dalam memutus perkara. Apabila yang tidak hadir ialah penggugat, maka gugatannya dapat dianggap tidak serius. Sedangkan apabila tergugat yang tidak hadir, maka memungkinkan bagi Majelis Hakim untuk memutus perkara secara Verstek. ${ }^{15}$ Jika para pihak hadir dan aktif turut aktif melaksanakan upaya perdamaian, maka proses mediasi akan berlangsung tidak lebih dari 40 (empat puluh) hari kerja sejak mediator dipilih oleh para pihak atau diangkat oleh Ketua Pengadilan Negeri. Atas dasar kesepakatan para pihak, masa mediasi dapat diperpanjang kembali untuk jangka waktu 14 (empat belas) hari kerja. Jika diperlukan, berdasarkan kesepakatan para pihak, mediasi dapat dilakukan dari jauh dengan menggunakan media komunikasi. Proses mediasi wajib dilaksanakan dengan itikad baik. Salah satu pihak dapat menyatakan diri untuk menarik diri dari proses mediasi jika pihak lain terbukti melakukan mediasi dengan itikad buruk.

Jika mediasi menghasilkan kesepakatan damai, para pihak dibantu oleh mediator harus merumuskan secara tertulis kesepakatan yang dicapai dan ditandatangani

15 Wawancara dengan Hari Trimadiyanto, S.H., M.H., Hakim Mediator di Pengadilan Negeri Jakarta Barat dilakukan di Jakarta pada hari Senin tanggal 16 April 2018.
Benny Djaja

Quo Vadis Undang-Undang Pokok Agraria...

oleh para pihak dan mediator. Sebelum para pihak menandatangani kesepakatan perdamaian atau mediasi tersebut, mediator memeriksa materi perjanjian perdamaian untuk menghindari kesepakatan yang melanggar hukum, tidak dapat diterapkan atau merugikan pihak ketiga. Para pihak kemudian akan kembali kepada hakim pada hari sidang yang ditunjuk untuk memberitahukan kesepakatan damai tersebut. Para pihak dapat mengusulkan kesepakatan damai kepada hakim untuk diperkuat dalam bentuk akta perdamaian, yang mana bersifat final and binding sebagaimana diatur dalam pasal 130 ayat (23) Reglement Acara Perdata yang Diperbaharui (HIR) juncto pasal 1858 KUHPerdata. Jika para pihak tidak menginginkan kesepakatan damai untuk dijunjung dalam bentuk akta perdamaian, perjanjian damai tersebut harus memuat klausul pencabutan gugatan dan / atau klausul yang menyatakan bahwa perkara tersebut telah selesai. ${ }^{16}$

Berdasarkan uraian diatas maka juga dapat ditarik kesimpulan bahwa syaratsyarat Kesepakatan Perdamaian yang dicapai, yang mana juga dimuat dalam pasal 27 ayat (2) Peraturan Mahkamah Agung Nomor 1 Tahun 2016 adalah sebagai berikut:

${ }^{16}$ Ibid., pasal 27 ayat (2). 


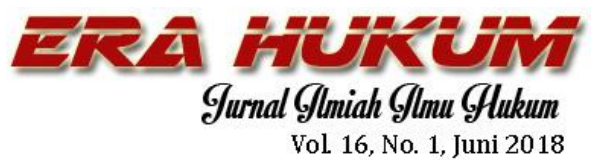

a. Tidak bertentangan dengan hukum, ketertiban umum dan / atau kesusilaan;

b. Tidak merugikan pihak ketiga;

c. Dapat dilaksanakan / enforceable.

Yang penting untuk diperhatikan ialah bahwa jiwa dari Peraturan Mahkamah Agung Nomor 1 Tahun 2016 tentang Prosedur Mediasi di Pengadilan menghendaki bahwa para pihak hadir secara langsung pada proses mediasi dan dengan mengecualikan kuasa hukum dari ruang sidang saat proses mediasi berlangsung. Ketentuan ini sangat berbeda dengan peraturan sebelumnya yang mengatur mediasi di pengadilan yaitu Peraturan Mahkamah Agung Nomor 1 Tahun 2008 yang memperbolehkan para pihak untuk diwakili oleh kuasa hukum saja pada tiap-tiap proses mediasi.

Peraturan Mahkamah Agung Nomor 1 Tahun 2016 tentang Prosedur Mediasi di Pengadilan merupakan suatu lembaga mediasi yang baik dan telah sesuai dengan asas cepat, sederhana dan biaya murah yang dianut konsep perdamaian atau mediasi di Indonesia. Mediasi di pengadilan ini jika lebih digalakkan lagi sosialisasinya dapat membuat penyelesaian sengketa pertanahan dan sengketa waris, sebagai perkara ketiga terbanyak menurut data pada Pengadilan Negeri Jakarta Barat menyusul perkara perceraian dan wanprestasi di po-
Benny Djaja

Quo Vadis Undang-Undang Pokok Agraria...

sisi pertama dan kedua, dapat dilakukan secara lebih efektif dan efisien lagi baik secara waktu maupun biaya. Namun demikian sangat disayangkan bahwa mediasi di pengadilan memiliki tingkat kesuksesan yang rendah oleh karena mentalitas para pihak yang berperkara di pengadilan yang sudah terbentuk "seolah ingin berperang" yang mana kemudian diperparah dengan masuknya saran-saran dari kuasa hukum yang seringkali tidak menginginkan perdamaian sebagai penyelesaian perkara. ${ }^{17}$

Hal lain yang menjadi faktor rendahnya tingkat keberhasilan mediasi di Pengadilan adalah posisi hakim mediator yang bukan hakim perkara. Kondisi ini ditambah dengan singkatnya jangka waktu proses mediasi di pengadilan yang menyebabkan hakim mediator tidak memiliki cukup waktu untuk memasuki pokok perkara dan mengolah perkara menjadi sebuah solusi untuk para pihak.

\section{B. Mediasi di Luar Pengadilan}

Di bidang pertanahan, mediasi di luar pengadilan di Indonesia dilakukan oleh Badan Pertanahan Nasional Republik Indonesia. Kedudukan Badan Pertanahan Nasional

17 Wawancara dengan Hari Trimadiyanto, S.H., M.H., Hakim Mediator di Pengadilan Negeri Jakarta Barat dilakukan di Jakarta pada hari Senin tanggal 16 April 2018. 


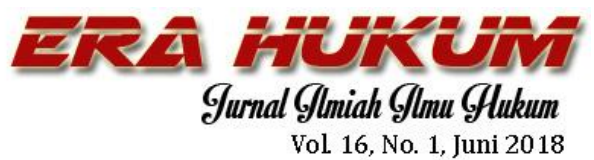

sebagai fasilitator sengketa pertanahan sebelum menuju kepada Pengadilan Negeri ialah karena tugasnya sebagai instansi Negara di bidang pertanahan. Salah satu misi dari Badan Pertanahan Nasional menurut Peraturan Presiden Republik Indonesia Nomor 63 Tahun 2013 tentang Badan Pertanahan Nasional Republik Indonesia adalah guna, "perwujudan tatanan kehidupan bersama yang harmonis dengan mengatasi berbagai sengketa, konflik dan perkara pertanahan di seluruh tanah air dan penataan perangkat hukum dan sistem pengelolaan pertanahan sehingga tidak melahirkan sengketa, konflik dan perkara di kemudian hari." Mediasi pada Badan Pertanahan Nasional dilakukan semata-mata sebagai fasilitator yang dengan itikad baik berusaha menjadi penengah yang baik bagi para pihak yang bersengketa. Badan Pertanahan Nasional maupun pegawainya bukan bertindak sebagai mediator yang ditunjuk berdasarkan hukum, karena seorang mediator haruslah berlisensi serta bukan merupakan Pegawai Negeri Sipil.

Mediasi di luar pengadilan yang dilakukan oleh Badan Pertanahan Nasional hanya dapat dilakukan berdasarkan kehendak dan kesepakatan kedua belah pihak yang bersengketa. Mediasi ini dilakukan guna mencapai win-win solution yang
Benny Djaja

Quo Vadis Undang-Undang Pokok Agraria...

menguntungkan para pihak, yang sangat kontras dengan suatu putusan pengadilan atas perkara yang memenangkan salah satu pihak. Mediasi di luar pengadilan ini biasanya hanya dilakukan sebanyakbanyaknya dalam 3 (tiga) kali pertemuan dan jika kesepakatan perdamaian tidak tercapai, maka sengketa akan dilanjutkan ke Pengadilan Negeri. ${ }^{18}$ Proses mediasi akan dan wajib dimulai di Kantor Pertanahan Daerah setempat daerah letak tanah yang menjadi obyek sengketa. Hal ini karena Kantor Pertanahan tersebut lah yang memiliki data-data fisik, yuridis, serta berkas-berkas pendaftaran tanah atas obyek tersebut. Akan tetapi jika para pihak merasa tidak puas jika mediasi hanya dilakukan di Kantor Pertanahan setempat, maka setelah bersepakat untuk melakukan mediasi, proses mediasi dapat dilakukan di Kantor Wilayah Badan Pertanahan Nasional setempat ataupun Badan Pertanahan Pusat.

Untuk proses perdamaian atau mediasi atas sengketa tanah yang belum bersertipikat, berdasarkan Undang-Undang Nomor 23 Tahun 2014 tentang Pemerintahan Daerah dilakukan di kantor Pemerintah Daerah setempat lokasi tanah obyek sengketa. Contoh dari mediasi untuk sengketa sejenis ini ialah mediasi sengketa

${ }^{18}$ Ibid. 


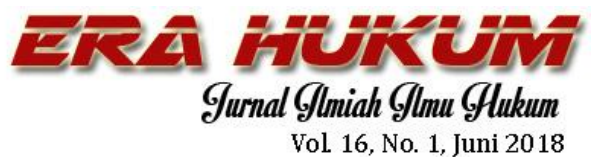

terkait Tanah Garapan.

Khusus untuk sengketa tanah-tanah bekas Hak Eigendom Barat maka tidak akan dilakukan mediasi atau perdamaian oleh Badan Pertanahan Nasional karena Menurut Peraturan Menteri Agraria Nomor 2 Tahun 1960 tentang Pelaksanaan Undang-Undang Pokok Agraria dalam rangka pelaksanaan unifikasi hukum tanah oleh Undang-Undang Pokok Agraria, Hak-hak Eigendom Barat dikonversi menjadi Hak Milik atau hak lainnya berdasarkan Undang-Undang Pokok Agraria, sesuai dengan terpenuhinya syarat-syarat subjektif kepemilikan hak atas tanah yang dimaksud, dalam jangka waktu paling lambat dua tahun sejak terbitnya Undang-Undang Pokok Agraria, yaitu terhitung sejak tanggal 24 September $1960^{19}$. Jika masih terdapat sisasisa hak barat dewasa kini dan tanahnya menjadi obyek sengketa tanah, sepanjang surat-surat perpajakan dan bukti pembayaran pajaknya lengkap dan tanahnya benar-benar dikuasai secara fisik oleh pihak yang mengaku memiliki hak tersebut, maka konversi atas hak tersebut menjadi Hak Guna Bangunan masih dapat dilakukan.

Dalam sebagian kasus sengketa pertanahan, Badan Pertanahan Nasional justru ditarik menjadi salah satu pihak yang ber-

${ }^{19}$ Ibid.
Benny Djaja

Quo Vadis Undang-Undang Pokok Agraria...

sengketa. Salah satu contoh kasus seperti ini ialah kasus penerbitan sertipikat ganda oleh Badan Pertanahan Nasional di mana yang bersengketa bukan hanya kedua belah pihak pemegang sertipikat yang berganda tersebut, namun juga Badan Pertanahan Nasional sebagai pihak yang menerbitkan sertipikat-sertipikat tersebut. Dalam kasuskasus demikian, Badan Pertanahan Nasional tidak menjamin dapat menjadi suatu penengah yang netral bagi penyelesaian sengketa pertanahannya dan akan berkecenderungan berkelit demi menutupi keberadaan kesalahan dari pihak Badan Pertanahan Nasional sendiri yang dapat saja menjadi penyebab utama timbulnya sengketa pertanahan tersebut.

Untuk menangani mediasi sengketa pertanahan di luar pengadilan sebetulnya terdapat satu lembaga yang bertugas khusus menangani mediasi perkara-perkara di luar pengadilan secara independen yaitu Badan Mediasi Indonesia (BAMI). Badan Mediasi Indonesia didirikan untuk memberikan suatu solusi penyelesaian sengketa yang memuaskan semua pihak, dengan berlandaskan pada itikad baik dan menjunjung tinggi keadilan. Dalam hal suatu sengketa pertanahan penyelesaiannya dilaksanakan melalui mediasi pada Badan Mediasi Indonesia, maka pertama-tama Mediator dari 


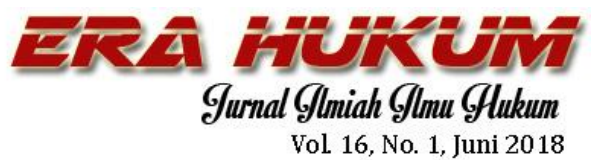

Badan Mediasi Indonesia dan para pihak akan dipertemukan, dalam pertemuan mana para pihak masing-masing akan diberikan kesempatan untuk saling mengemukakan tentang duduk permasalahan serta bentuk penyelesaian yang di harapkan. Dalam proses mediasi yang dilakukan, mediator bertindak sebagai penengah dan menjaga agar diskusi tetap dalam suasana yang kondusif. Mediator kemudian akan mempelajari sengketanya berdasarkan bukti-bukti dari kedua belah pihak dan akan menawarkan usulan solusi yang adil bagi kedua belah pihak untuk dapat diterima sebagai kesepakatan yang dihasilkan. Mediator hanya menawarkan usulan-usulan yang positif dan tidak memihak, namun keputusan akhir yang dihasilkan tetap menjadi keputusan kedua belah pihak yang bersifat pribadi dan rahasia serta tidak dipublikasikan. Diharapkan perdamaian akan berhasil. Jika para pihak mencapai mufakat, maka perjanjian perdamaian antara para pihak akan dibuat dan kemudian ditandatangani oleh para pihak dan mediator. Namun demikan jika usulan perdamaian tidak dapat disetujui oleh salah satu pihak atau keduanya, dan mediasi menjadi gagal, maka atas persetujuan kedua belah pihak, sengketa dapat diteruskan ke proses arbitrase ad hoc. Perjanjian perdamaian me-
Benny Djaja Quo Vadis Undang-Undang Pokok Agraria...

lalui mediasi ataupun putusan yang dijatuhkan oleh arbiter/arbitrator ad hoc kemudian langsung bersifat final dan mengikat, serta hanya bisa dibatalkan karena sebab-sebab yang sangat terbatas, sebagaimana ditentukan dalam pasal 70 Undang-Undang Nomor 30 Tahun 1999 tentang Arbitrase dan Alternatif Penyelesaian Sengketa.

\section{Penyelesaian Sengketa Pertanahan Melalui Perkara dalam Peradilan}

Sekiranya penyelesaian melalui mediasi dalam pengadilan antara para pihak tidak tercapai, demikian juga jika penyelesaian secara damai melalui perantara Badan Pertanahan Nasional tidak dapat diterima oleh pihak-pihak yang berselisih, penyelesaian sengketa pertanahan harus dilakukan melalui jalur pengadilan. Penyelesaian sengketa pertanahan di pengadilan mengikuti alur persidangan perkara perdata sebagaimana diatur dalam Hukum Acara Perdata yang dianut di Indonesia, yang diantaranya diatur dalam Kitab Undang-Undang Hukum Perdata (KUHPerdata), Reglement Acara Perdata (RBG) dan Reglement Acara Perdata yang Diperbaharui (HIR).

Secara garis besar, tahap selanjutnya dari pemeriksaan perkara perdata pasca tid- 


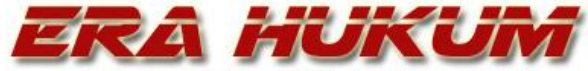 \\ Gurnal Glmiah Glmu Glukum \\ vol 16, No. 1, Juni 2018}

ak tercapainya penyelesaian melalui mediasi di pengadilan ialah sidang lanjutan dengan agenda pembacaan tuntutan hukum oleh penggugat dan pemberian jawaban dari tergugat. Penggugat dan tergugat kemudian akan saling membantah jawaban dari satu sama lain dalam tahapan sidang dengan agenda pembacaan replik oleh penggugat dan duplik dari tergugat, sebelum akhirnya sidang akan memasuki tahap pembuktian. Proses pembuktian akan dilakukan secara mendalam dan menyeluruh oleh masing-masing pihak guna meyakinkan hakim yang memeriksa perkara berdasarkan fakta hukum dan bukti-bukti yang ada akan kebenaran gugatan masingmasing pihak yang berperkara. Tahapan ini merupakan tahapan yang panjang dan memakan waktu, biaya serta tenaga yang banyak di mana bukti-bukti tertulis, keterangan para saksi dan saksi-saksi ahli, serta berbagai alat bukti lain akan diperdengarkan dan diperiksa dalam persidangan. Pembuktian akan terus dilakukan sebelum akhirnya para majelis hakim yang mengadili persidangan dapat mencapai suatu kesimpulan. Barulah kemudian putusan perkara akan dibacakan dalam suatu sidang tersendiri dengan agenda sidang pembacaan putusan perkara perdata. $^{20}$

${ }^{20}$ Mahkamah Agung Republik Indonesia, Website
Benny Djaja

Quo Vadis Undang-Undang Pokok Agraria...

Dalam proses persidangan yang panjang ini, masih dimungkinkan untuk dilakukan perdamaian. Bila salah satu pihak melihat bahwa bukti-bukti yang ada akan melemahkan posisinya, maka pihak tersebut dapat mendekati pihak lawannya untuk kemudian, jika kedua belah pihak setuju, melakukan proses perdamaian.

Proses yang harus ditempuh oleh para pihak yang berperkara dalam penyelesaian sengketa pertanahan melalui pengadilan sangatlah panjang dan menguras waktu, tenaga serta biaya. Oleh karenanya menurut hemat penulis, penyelesaian sengketa tanah melalui pengadilan ini seharusnya menjadi ultimum remedium yang seharusnya hanya ditempuh setelah mencoba segala macam usaha perdamaian yang memungkinkan, dan bukan menjadi go-to option setiap kali terjadi suatu konflik terkait hak atas tanah. Terlebih lagi jika dilihat dari segi spesialisasinya, penyelesaian sengketa pertanahan melalui pengadilan masih dilakukan melalui lembaga peradilan perdata yang bersifat umum dan tidak terspesialisasi bidang pertanahan. Hal ini sangatlah kontras dengan upaya penyelesaian melalui

Pengadilan Negeri Curup, http://www.pncurup.go.id/index.php/2017-05-03-04-3128/kepaniteraan-perdata/alur-persidangan-perdata, Alur Persidangan Perkara Perdata, diakses pada Rabu, 16 Mei 2018, jam 15.00. 


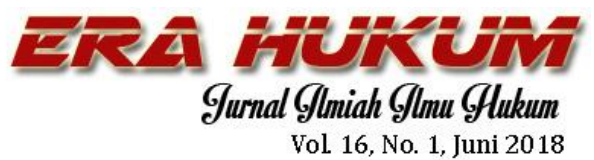

perdamaian dengan perantara Badan Pertanahan Nasional Pusat yang memang merupakan lembaga negara yang khusus menangani bidang pertanahan di Indonesia menurut Peraturan Presiden Republik Indonesia Nomor 63 Tahun 2013 tentang Badan Pertanahan Nasional Republik Indonesia, atau pun penyelesaian sengketa melalui proses mediasi di pengadilan dengan mediator yang dapat diseleksi sesuai dengan keahliannya di bidang sengketa pertanahan yang sedang dihadapi.

Undang-Undang Pokok Agraria dengan limapuluh delapan pasalnya dan juga sembilan pasal-pasal konversinya sama sekali tidak menunjuk peradilan yang khusus untuk menangani masalah Agraria secara umum ataupun pertanahan secara khusus. Melihat telah diadakannya lembaga peradilan khusus seperti peradilan perikanan di Pengadilan Negeri Jakarta Utara, berdasarkan Undang-undang Nomor 31 Tahun 2004 tentang Perikanan, yang banyak menangani perkara perikanan, ataupun keberadaan Pengadilan Hubungan Industrial, berdasarkan Undang-Undang Nomor 2 Tahun 2004 tentang Penyelesaian Perselisihan Hubungan Industrial (PPHI), yang bertugas khusus mengadili sengketasengketa ketenagakerjaan dan harus diakui keduanya sangat berhasil membantu me-
Benny Djaja Quo Vadis Undang-Undang Pokok Agraria...

nyelesaikan perselisihan secara berturutturut di bidang perikanan dan ketenagakerjaan serta mengurangi beban peradilan perdata umum. Seharusnya melihat besarnya skala jumlah sengketa pertanahan yang masuk ke dalam lembaga peradilan di Indonesia, sudah sangat penting dan mendesak untuk diadakan suatu lembaga peradilan khusus tersendiri yang hanya menangani sengketa pertanahan di Republik Indonesia. Lembaga Peradilan khusus sengketa pertanahan ini kemudian harus bekerjasama lebih erat dengan Badan Pertanahan Nasional Republik Indonesia guna menyelesaikan sengketa pertanahan yang masuk secara lebih efektif dan efisien lagi, dan bahkan dengan kerjasama tersebut dapat turut berkontribusi menyediakan lembaga mediasi, baik di dalam maupun di luar pengadilan, dengan tingkat kesuksesan perdamaian yang lebih tinggi lagi.

Dalam usianya yang ke-58 tahun, Undang-Undang Pokok Agraria masih tetap kokoh sebagai banteng untuk masalah keagrariaan di negeri ini walaupun sudah terasa tertinggal oleh zaman. Namun demikian, sebagaimana telah diuraikan diatas, ketertinggalan ini akan dapat diatasi bila saja pemerintah dan pembentuk undang-undang mengambil tindakan dengan tujuan yang terfokus pada mening- 


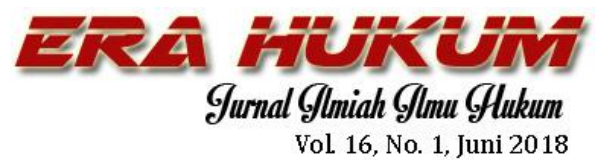

katkan efektivitas dan efisiensi penyelesaian sengketa pertanahan yang mana Undang-Undang Pokok Agraria menjadi payung hukum utamanya.

\section{Kesimpulan}

Kasus sengketa pertanahan merupakan salah satu jenis perkara terbanyak yang ditangani oleh lembaga peradilan di Indonesia menyusul kasus perceraian dan wanprestasi. Dua sebab yang cukup banyak menimbulkan permasalahan sengketa tanah ialah terkait proses pendaftaran tanah dan peristiwa pewarisan. Sistem pendaftaran tanah di Indonesia sesuai Peraturan Pemerintah Nomor 24 Tahun 1997 tentang Pendaftaran Tanah yang menganut stelsel negatif dengan mengandung unsur positif yakni bahwa setelah lima tahun sertipikat tanah menjadi tidak dapat diganggu gugat, walaupun di satu sisi memberikan kepastian hukum dan perlindungan hukum, namun di sisi lain juga riskan dan menimbulkan kemungkinan sengketa tanah atas hak dalam sertipikat tersebut. Terkait peristiwa pewarisan rata-rata penyebab timbulnya konflik/ sengketa tanah dalam pembagian harta warisan dapat berasal dari faktor internal, seperti adanya hibah orang tua kepada bakal ahli waris, tetapi tidak adil dan tidak disertai akta hibah, pasangan
Benny Djaja Quo Vadis Undang-Undang Pokok Agraria...

suami istri (sebagai bakal pewaris) yang tidak memiliki anak atau keturunan, dan yang berasal dari faktor eksternal, seperti: adanya anak angkat yang diberi hibah oleh orang tua angkatnya, dan harta warisan dipinjamkan kepada kerabat yang bukan ahli waris dan tidak dikembalikan.

Perdamaian atau mediasi atas sengketa pertanahan dapat dilakukan baik di dalam Pengadilan maupun diluar pengadilan. Di dalam pengadilan, mediasi diatur prosedurnya dalam Peraturan Mahkamah Agung Nomor 1 Tahun 2016 tentang Prosedur Mediasi di Pengadilan dan dilakukan antara para pihak dengan perantara Mediator tersertifikasi yang dapat ditunjuk dari hakim Mediator yang bukan pemeriksa pengadilan di pengadilan yang bersangkutan, kalangan advokat atau akademisi hukum, profesi non-hukum yang dianggap sebagai tuan rumah atau berpengalaman dalam masalah perselisihan, hakim dari pemeriksa kasus terkait, atau kombinasi diantaranya. Berdasarkan penelitian, mediasi di pengadilan memiliki tingkat keberhasilan yang rendah terutama karena mentalitas para pihak yang berperkara di pengadilan yang sudah terbentuk "seolah ingin berperang”. Hal tersebut sangat disayangkan karena mediasi di pengadilan merupakan suatu lembaga mediasi yang 


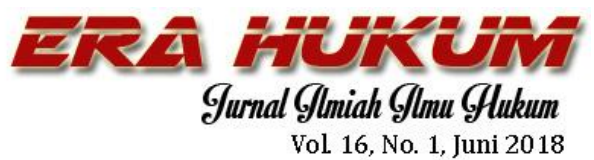

sangat penting. Melihat dari asas cepat, sederhana, dan biaya murah yang dianut konsep perdamaian atau mediasi di Indonesia, mediasi di pengadilan ini jika lebih digalakkan lagi sosialisasinya dapat membuat penyelesaian sengketa pertanahan dapat dilakukan secara lebih efektif, dan efisien lagi baik secara waktu maupun biaya. Di luar pengadilan, mediasi sengketa pertanahan di luar pengadilan di Indonesia dilakukan oleh Badan Pertanahan Nasional Republik Indonesia. Kedudukan Badan Pertanahan Nasional sebagai fasilitator sengketa pertanahan sebelum menuju kepada Pengadilan Negeri ialah karena tugasnya sebagai instansi Negara di bidang pertanahan. Fungsi ini ialah bagian dari misi Badan Pertanahan Nasional sebagaimana diatur Peraturan Presiden Republik Indonesia Nomor 63 Tahun 2013 tentang Badan Pertanahan Nasional Republik Indonesia.

Dalam usianya yang ke-58 tahun, Undang-undang Nomor 5 tentang PokokPokok Agraria yang menjadi peraturan dasar pertanahan tersebut dirasa masih relevan sebagai payung hukum penyelesaian masalah keagrariaan di negera Republik Indonesia. Namun demikian mekanisme penyelesaian sengketa yang ditawarkan oleh Undang-undang Pokok Agraria maupun peraturan-peraturan pelaksananya tera-
Benny Djaja Quo Vadis Undang-Undang Pokok Agraria...

sa sangat primitif. Dengan penyelesaian perkara melalui peradilan yang masih menjadi go to option dalam mayoritas penyelesaian sengketa pertanahan, melihat mahalnya biaya serta lamanya waktu yang dibutuhkan, hal ini sangat menghambat penyelesaian sengketa pertanahan dan bertendensi menjadi medan "perang uang" antara para pihak yang berperkara. Jika terus begini, haruslah dipertanyakan "Qua Vadis Undang-Undang Pokok Agraria Republik Indonesia?" Ketertinggalan ini hanya dapat diatasi bila pemerintah dan pembentuk undang-undang mengambil tindakan dengan tujuan yang terfokus pada meningkatkan efektivitas dan efisiensi penyelesaian sengketa pertanahan yang mana Undangundang Pokok Agraria menjadi payung hukum utamanya. Selamat ulang tahun yang ke-58 Undang-undang Pokok Agraria.

\section{Saran}

Diperlukan adanya Nota Kesepakatan atau Memorandum of Understanding antara Mahkamah Agung Republik Indonesia dengan Badan Pertanahan Nasional Pusat yang pada intinya menyepakati bahwa Mahkamah Agung bekerjasama untuk menyediakan sarana pelatihan mediasi untuk pegawai Badan Pertanahan Nasional se- 


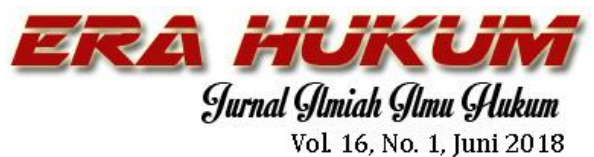

bagai fasilitator perdamaian sengketa tanah. Pada tiap-tiap sengketa tanah kemudian Badan Pertanahan Nasional akan dapat melakukan mediasi di luar pengadilan terlebih dahulu. Laporan dari hasil mediasi tersebut kemudian akan digunakan sebagai bahan dasar untuk mediasi melalui Pengadilan Negeri. Selain itu, untuk perkaraperkara di mana Badan Pertanahan Nasional dirasa tidak cocok untuk menjadi penengah perkara, penyelesaian sengketa pertanahan melalui lembaga mediasi independen yaitu Badan Mediasi Indonesia (BAMI) harus lebih luas disosialisasikan dan ditingkatkan efektivitasnya lagi demi tercapainya penyelesaian sengketa yang jauh lebih cepat, sederhana dan dengan biaya relatif terjangkau.

Saran lain yang diberikan berdasarkan penelitian dan pengamatan yang dilakukan ialah perlunya pendirian suatu lembaga peradilan tersendiri yang khusus untuk menangani sengketa-sengketa pertanahan, yaitu peradilan pertanahan, baik untuk melaksanakan mediasi di dalam pengadilannya maupun penyelesaian perkara melalui peradilannya. Pendirian lembaga peradilan pertanahan tersebut dirasa sangat penting dan mendesak mengingat tingginya jumlah perkara sengketa pertanahan yang sampai ke meja hijau lembaga peradilan di
Benny Djaja Quo Vadis Undang-Undang Pokok Agraria...

Indonesia. Keberadaan lembaga peradilan pertanahan tersebut dalam perkembangannya juga niscaya didorong dengan penerbitan peraturan perundang-undangan yang mendukung Undang-Undang Nomor 5 Tahun 1960 tentang Pokok-Pokok Agraria sebagai payung hukum untuk masalah pertanahan di Republik Indonesia khususnya di bidang penyelesaian sengketa pertanahan sehingga dapat meningkatkan efektivitas dan efisiensi penyelesaian sengketa pertanahan di Indonesia, baik melalui lembaga peradilan, atau pun melalui jalur perdamaian.

\section{DAFTAR PUSTAKA}

\section{A. Buku}

Kementerian Agraria dan Tata Ruang / Badan Pertanahan Nasional. Anotasi Putusan Pengadilan Mengenai Pertanahan Tentang Waris. Cet. 1. Jakarta : Biro Hukum dan Hubungan Masyarakat Kementerian Agraria dan Tata Ruang / Badan Pertanahan Nasional, 2016.

Anotasi Putusan Pengadilan Mengenai Pertanahan Jilid 5 (Terkait Pasal 32 Ayat (2) Peraturan Pemerintah Nomor 24 Tahun 1997 Tentang Pendaftaran Tanah, Cet. 1 (Jakarta : Biro Hukum dan Hubungan Masyarakat Kementerian 
Agraria dan Tata Ruang / Badan

Pertanahan Nasional, 2015)

Leks, Eddy M. Panduan Praktis Hukum Properti : Memahami Problematika Hukum Pertanahan, Perumahan, serta Pengembangannya. Cet. 1. Jakarta: PT Gramedia Pusaka Utama, 2016.

\section{B. Peraturan Perundang-undangan}

. Undang-Undang Republik

Indonesia tentang Arbitrase dan

Alternatif Penyelesaian

Sengketa. UU No. 30 Tahun

1999. LN No.138 Tahun 1999,

TLN No.3872.

. Undang-Undang Republik

Indonesia tentang Peraturan

Dasar Pokok-Pokok Agraria. UU

No. 5 Tahun 1960. LN No.104

Tahun 1960, TLN No.2043.

Mahkamah Agung Republik Indonesia.

Pertaturan Mahkamah Agung

Tentang Prosedur Mediasi Di

Pengadilan. Nomor 1 Tahun

2016.

\section{Lain-lain}

Asni Zubair, http://roufartikel.blogspot.com/2012/11/pe nyelesaian-hukum-waris.html, Disertasi Uin Sunan Kalijaga, 2013, diunduh pada Senin, 9 April 2018, jam 13.30 WIB.
Curup, http://www.pncurup.go.id/index.php/2017-0503-04-31-28/kepaniteraanperdata/alur-persidangan-perdata, Alur Persidangan Perkara Perdata, diakses pada Rabu, 16 Mei 2018, jam 15.00.

Mahkamah Agung Republik Indonesia, Website Pengadilan Negeri 